\title{
Paham Dan Upacara Kematian Dalam Agama Marapu Sebagai Wadah Evangelisasi Iman Kristiani Di Sumba-Nusa Tenggara Timur
}

\author{
Konradus Doni K. ${ }^{1}$, Silvester Nusa ${ }^{2}$ \\ ${ }^{1}$ Program Studi Pendidikan Bahasa Indonesia, Sekolah Tinggi Keguruan dan Ilmu Pendidikan Weetebula; \\ ${ }^{2}$ Program Studi Pendidikan Keagamaan Katolik, Sekolah Tinggi Keguruan dan Ilmu Pendidikan Weetebula
}

\author{
*Corresponding Author: \\ Konradus Doni K, Program \\ Studi Pendidikan Bahasa \\ Indonesia, Sekolah Tinggi \\ Keguruan dan Ilmu \\ Pendidikan Weetebula; \\ Email: \\ kleden_doni@yahoo.co.id
}

\begin{abstract}
Abstrak: Agama apapun dalam karya pewartaan dan misinya selalu dihadapkan dengan budaya lokal, yang di dalamnya ada agama lokalnya juga. Misi 'tradisional' agama-agama modern selama ini cenderung 'memusnahkan' agama dan budaya lokal karena dianggap sebagai penghalang penyebaran agama-agama modern itu. Fakta menunjukkan bahwa ada banyak resistensi dari masyarakat lokal (insider) terhadap tuntutan agama modern seperti itu. Mereka merasa tercabut dari akar kehidupan mereka. Akibat lebih lanjut adalah iman mereka pun dangkaldangkal saja, selain misi ditolak. Banyak orang memeluk agama-agama modern hanya karena tuntutan sosial dan administrasi pemerintahan, bukan karena suatu pengakuan akan iman agama-agama modern. Cara bermisi seperti inilah yang saya lihat kurang pas. Penelitian ini mencoba menggunakan paham-paham dan upacara-upacara budaya khususnya dalam hal kematian sebagai wadah misi (evangelisasi), dan tidak dilihat sebagai penghalang. Penelitian ini menggunakan metode observasi dan wawancara dalam mengumpulkan data, sementara pembahasannya menggunakan metode kualitatif etnografis (deskriptif). Tujuan jangka panjang dari hasil penelitian ini adalah menjadi pedoman pastoral untuk evangelisasi iman kristiani di Sumba. Sementara target khusus yang ingin dicapi dari penelitian ini adalah memberi pemahaman baru dan juga sekaligus solusi berpastoral yang selama ini dianggap berat dan sulit karana benturan budaya yang sulit ditembus.
\end{abstract}

Keywords: Evangelisasi

\section{Pendahuluan}

Karya misi Gereja bertemu dan bergaul dengan unsur-unsur di luar Gereja (agama lain, kebudayaan setempat dan situasi sosial kemasyarakatan) dan mengajak mereka untuk berziarah bersama menuju kepada Allah. Untuk maksud ini Gereja harus bersikap terbuka dengan situasi konkret yang ada di sekitarnya. Gereja sebagai himpunan orang beriman, tidak perlu menciptakan harapan-harapan misioner yang mustahil dapat tercapai, seperti kecenderungan untuk secara institusional mengkristenkan dunia. Hal ini berarti bahwa Gereja Lokal harus dapat hidup dan melaksanakan misi sesuai dengan tuntutan Injil untuk menjawab situasi konkret manusia, di mana ia hidup dan mau berakar sampai ke dalam sel-sel kebersamaan yang paling kecil (Edmund, 2002:220). Gereja dan kita pun harus sadar bahwa Allah yang mewahyukan Diri kepada umat-Nya hingga penampakan Dirinya sepenuhnya dalam Putera-Nya yang menjelma, telah bersabda menurut kebudayaan yang khas bagi pelbagai zaman (GS 58). Begitu pula Gereja, yang sepanjang zaman hidup dalam pelbagai situasi, telah memanfaatkan sumber-sumber aneka kebudayaan, untuk menyebarluaskan dan mewartakan Kristus kepada semua bangsa. 
Seperti dikatakan oleh Konsili bahwa Gereja tidak menolak ilai-nilai yang benar dan suci (GS 53, NA 2), begitu pula sebaliknya, Gereja di dalam karya misinya dengan cara yang tepat menawarkan nilai-nilai yang dihayatinya agar tidak ditolak oleh agama dan budaya setempat. Penolakan terhadap Gereja tidak pertama-tama berarti penolakan terhadap Allah, tetapi harus ditafsir sebagai ketidak berhasilan Gereja dalam melaksanakan tugasnya sebagai sakramen keselamatan Allah. Dalam terang pemahaman yang demikian ini, saya mencoba membaca dan meneliti sekaligus melihat peluang ajaran dan pengahayatan agama Marapu dalam proses evangelisisasi iman Kristiani di Sumba yang selama ini dirasa sebagai tantangan dan hambatan. Ini menjadi keprihatinan peneliti. Dalam arti ini pula peneliti mencoba melihatnya secara lain dan mencoba mencari titik temu untuk menjadikan agama marapu sebagai wadah evangelisasi khususnya terkait dengan paham kematian, bukannya sebagai penghalang. Tegasnya peneliti mau melihat peluang pastoral (evangelisasi) dari pemahaman dan upacara kematian dalam Agama Marapu.

Untuk memahami dan mengerti bagaimana kehidupan dan budaya masyarakat Sumba pada umumnya dan Sumba Barat Daya pada khususnya, perlu diketahui dulu kepercayaan (agama) mereka yang sampai sekarang masih kuat dipertahankan. Memahami konteks kehidupan orang Sumba, hanya bisa ditelusuri melalui sistem kepercayaan mereka. Sistem kepercayaan ini juga yang membentuk cara hidup mereka. Dengan kata lain, segi-segi kehidupan lain bisa diatur berdasarkan amanah atau sistem yang terdapat dalam agama Marapu itu sendiri. Karena itu orang sering mengatakan bahwa; mengenal Sumba berarti mengenal Marapu; Sumba berarti Marapu dan Marapu berarti Sumba. Jalan masuk mengenal Sumba hanya melalui Marapu1. Ada keterkaitan antara hidup sosial dan sistem kepercayaan (Bdk.Radcliffe-Brown, 1965: 153, Sahlins 1968:96, Keesing, 1992:97)

Agama Marapu merupakan sebuah kepercayaan lokal, baik di Sumba Timur maupun di Sumba Barat. Mereka percaya akan kekuatan yang

${ }^{1}$ Wellem (2004:41), Fowler (1999:130), Hoskins (1987:136), Gunawan (2007:37), Tunggul (2000:23, 2003: 21), Yewangoe (1980:52), Hambarandi (1982:51), Kapita (1976), Forshee (1996:23) ada di luar dunia manusia yang masih mempengaruhi dan bahkan menentukan hidup mereka. Kekuatan itu adalah kekuatan dari para leluhur atau nenek moyang mereka. Oleh karena itu kepercayaan Marapu ini merupakan penyembahan kepada leluhur atau nenek moyang. Munculnya keyakinan akan adanya kekuatan-kekuatan gaib merupakan perwujudan dari kebutuhan manusia yang mencari keamanan, perlindungan dan ketenteraman (Fernandez, 1990:296; Soh, dkk., 1985:76). Dalam ritual agama Marapu ini, mereka mempersembahkan korban, seperti ayam, babi dan hasil panen lainnya untuk "yang tertinggi" dan juga untuk leluhur mereka, karena mereka percaya bahwa, leluhur mereka tetap ada bersama mereka, menjaga dan melindungi mereka. Oleh karena itu upacara sesaji adalah saat mereka bisa berkomunikasi dengan leluhur. Kepercayaan Marapu muncul dari konsep bahwa orang yang masih hidup harus senantiasa menjaga keharmonisan dengan roh nenek moyangnya.

Tema yang diangkat dalam penelitian ini sesungguhnya bukanlah sebuah tema yang sama sekali baru. Paling tidak sudah ada dua penelitian tentang ritual kematian dalam budaya Sumba Barat Daya, khususnya Suku Wewewa.

Dony Kleden dalam bukunya yang berjudul Politik Resiprositas Kedde, mengurai secara jelas dan rinci tentang tahapan upacara pemakaman di Suku Wewewa. Yang menjadi fokus kajian dalam buku ini, yang juga adalah hasil dari penelitiannya adalah kearifan dan manipulasi dalam kedde kematian. Kedde artinya prosesi sekelompok orang yang membawa hewan untuk membantu kekurangan keluarga yang mengalami kesedihan karena adanya kematian anggota keluarga. Dari hasil penelitiannya sebagaimana yang tertulis dalam bukunya ini, Dony Kleden menyimpulkan bahwa, prosesi kedde itu ternyata tidak mempunyai motivasi tunggal sebagaimana yang dipercaya oleh banyak orang, tetapi mempunyai makna plural. Arti kedde tidak hanya solidaritas dengan kerabat yang sedang berkesusahan, tetapi juga mempunyai muatan politik dan lain sebagainya. Juga ditemukan bahwa, seringkali ada rekayasa di balik prosesi itu.

Cyntia T. Fowler (2003), dalam salah satu karyanya, menulis tentang budaya resiprositas yang biasa dilakukan oleh orang-orang Sumba. Namun fokus dari Cynthia T. Fowler ini adalah pada relasi antara orang-orang yang masih hidup dengan para leluhur. Dalam tulisannya yang berjudul "The 
Ecological Implications of Ancestral Religion and Reciprocal Exchange In A Sacred Forest in Karendi (Sumba-Indonesia)", Fowler menegaskan bahwa ada tradisi yang cukup kuat antara orang-orang yang masih hidup dengan para leluhur untuk saling mengadakan tukar-menukar. Untuk mendapatkan keberuntungan dalam hidup, hasil panen yang baik, kesehatan yang baik dan segala kebaikan lainnya, bebas dari segala petaka, orang Sumba harus selalu memberi korban atau sesaji kepada para leluhur.

Berdasarkan kajian pustaka tersebut, bisa diposisikan atau ditempatkan fokus analisis dalam tulisan ini yang membedakannya dengan yang sudah ada, bahwa tema penelitian dan tulisan ini bukanlah tema yang baru sam sekali. Kendati pun demikian dalam buku ini, analisisnya difokuskan pada titik temu antara pemahaman atau konsep kematian dalam Agama Marapu dan Katolik. Penelitian ini berusaha mencari titik temu yang bisa dijadikan pintu masuk untuk berbicara tentang iman Katolik secara lebih menyentuh. Dan sejauh ini, tema penelitian dengan fokus yang demikian ini belum pernah dilakukan oleh siapa pun.

\section{Metode Penelitian}

Penelitian ini merupakan penelitian kualitatif etnografis (deskriptif), di mana peneliti secara etnografis menceritakan apa yang tengah terjadi di masyarakat Wewewa Sumba Barat Daya, khususnya dalam kaitan dengan pemahaman atau filosofi dan sekaligus teologi kematian dalam agama marapu beserta alasan di balik setiap ritual kematian yang selalu dihadirkan. Metode ini memiliki tujuan untuk bisa mengumpulkan data secara detail, mendalam dan juga aktual. Penelitian kualitatif adalah metode penelitian yang berfokus pada pemahaman terhadap fenomena sosial yang terjadi di masyarakat. Sementara itu pendekatan etnografi merupakan salah satu strategi kualitatif yang di dalamnya peneliti menyelidiki suatu kelompok kebudayaan di lingkungan yang alamiah dalam periode waktu yang cukup lama.

Dalam pengumpulan data utama, data observasi partispatif dan data wawancara. James Spradley $^{2}$ yang adalah seorang etnograf terkenal menjelaskan etnografi sebagai deskripsi atas suatu kebudayaan untuk memahami suatu pandang emik atau insider (sudut pandang penduduk asli).

\footnotetext{
${ }^{2}$ James Spradley (1997) Metode Etnografi (terjemahan), Yogyakarta:PT Tiara Wacana Yogya
}

Spradley dalam konteks ini lebih menekankan penelitian lintas budaya (cross culture research). Alasan di balik cross culture research ini adalah semata-mata demi obyektivitas hasil yang diperoleh. Seorang outsider bagi Spradley akan lebih sensitif dan obyektif dalam membaca dan mengolah data. Ini juga menjadi alasan peneliti memilih budaya Sumba dan bukan budayanya sendiri.Budaya menjadi jalan masuk untuk memahami kehidupan suatu masyarakat.

Pada metode penelitian ini, peneliti menggunakan perspektif dari partisipan (observasi partisipasi) sebagai gambaran yang diutamakan dalam memperoleh hasil penelitian. Spradley dalam hal ini mempunyai pemahaman yang sama dengan Jorgensen (1989) ..."direct observation is the primary method of gathering information.

Ada beberapa konsep yang menjadi fondasi bagi metode penelitian etnograf ini. Pertama, Spradley mengungkapkan pentingnya membahas konsep bahasa, baik dalam melakukan proses penelitian maupun saat menuliskan hasilnya dalam bentuk verbal. Kebudayaan dalam dogma budaya antropologi tersimpan dalam bahasa. Seorang peneliti penting mempelajari bahasa setempat. Walaupun demikian Spradley telah menawarkan sebuah cara yaitu dengan mengajukan pertanyaan etnograf. Konsep kedua adalah informan. Etnografer bekerja sama dengan informan untuk menghasilkan sebuah deskripsi kebudayaan. Informan merupakan sumber informasi.

Spradley mengungkapkan tentang langkahlangkah melakukan penelitian wawancara etnografis sebagai langkah kesimpulan dengan metode etnografi. Wawancara etnografis merupakan jenis peristiwa percakapan (speech event) yang khusus. Tiga unsur yang penting dalam wawancara etnografis adalah tujuan yang eksplisit, penjelasan dan pertanyaannya yang bersifat etnografis langkah selanjutnya adalah membuat catatan etnografis. Sebuah catatan etnografis meliputi catatan lapangan, alat perekam gambar, artefak dan benda lain yang mendokumentasikan suasana budaya yang dipelajari. Langkah keempat adalah mengajukan pertanyaan deskriptif. Pertanyaan deskriptif mengambil "keuntungan dari kekuatan bahasa yang menafsirkan setting" (frake dalam Spradley,1997). Etnografer perlu untuk mengetahui paling tidak satu seting yang di dalamnya informan melakukan aktivitas rutinnya. Langkah kelima adalah melakukan analisis wawancara etnografis. Analisis ini merupakan 
penyelidikan berbagai bagian sebagaimana yang dikonseptualisasikan oleh informan. Langkah keenam yakni membuat analisis domain. Analisis ini dilakukan untuk mencari domain awal yang memfokuskan pada domain-domain yang merupakan nama-nama benda. Langkah ketujuh ditempuh adalah mengajukan pertanyaanpertanyaan struktural yang merupakan tahap lanjut setelah mengidentifikasi domain. Langkah selanjutnya adalah membuat analisis taksonomik. Langkah kesembilan yakni mengajukan pertanyaan kontras di manakah nilai-nilai tersirat yang berbeda dengan lain. Langkah kesepuluh adalah analisis komponen. Analisis komponen merupakan suatu pencarian sistematik berbagai atribut (komponen nilai-nilai) yang berhubungan dengan ritus budaya. Langkah kesebelas menemukan tema-tema budaya. Langkah terakhirnya yakni menulis sebuah etnografis.

Di dalam sebuah penelitian biasanya akan di jelaskan mengenai gejala-gejala yang sudah ada misalnya tentang masalah serta meneliti kondisi yang tetap berlaku. Dalam penelitian ini, metode etnografi digunakan untuk mengungkap gambaran umum mengenai nilai-nilai dan pemahaman masyarakat tentang kematian dan segala ritual yang ada. Penelitian ini juga menjadikan perbandingan tentang apa yang bisa di lakukan untuk menentukan sebuah solusi dalam menghadapi sebuah permasalahan.

\section{Tahapan Penelitian}

Tahapan penelitian ini memuat skema berupa alur atau proses penelitian mulai dari tahapan, metode yang digunakan masing-masing tahapan, dan menjawab masalah apa hingga tujuan akhir penelitian. Terkait dengan tahapan-tahapan yang dimaksud ini, maka tahap yang paling awal adalah penentuan informan di lokasi penelitian. Tahap berikutnya adalah mengumpulkan informasi (tahap mencari dan mengumpulkan data). Datadata tersebut diperoleh dari hasil wawancara (cakap) peneliti dengan informan. Wawancara dilakukan dengan para tokoh adat atau orang yang dituakan pada masyarakat suku Wewewa, khususnya Desa Wali Ate. Data yang telah diperoleh, dipilah, dipilih dan dikelompokkan atau diklasifikasikan serta dikaji atau dianalisis dengan menggunakan teori Resiprositas.

Sebelum peneliti melakukan penganalisisan data, terlebih dahulu penulis melakukan pengumpulan data dengan menggunakan metode simak, metode cakap dan metode refleksi/introspeksi. Pada akhir dari kajian atau analisis ini diperoleh sebuah kesimpulan dan juga saran. Terkait dengan tema yang diteliti, maka simpulan yang akan ditemukan adalah bagaimana pemahaman dan upacara pemakaman bisa menjadi wadah dalam melakukan evangelisasi. Sementara itu saran dibuatkan juga dengan maksud untuk memberikan cara pikir baru atau metode baru dalam berpastoral dengan budaya lokal sebagai wadahnya. Dalam arti ini budaya lokal yang dikonfrontasikan dengan evangelisasi sebagaimana yang selama ini terjadi justru akan menjadi wadah bagi evangelisasi.

Adapun bagan rancangan penelitian ini sebagai berikut.

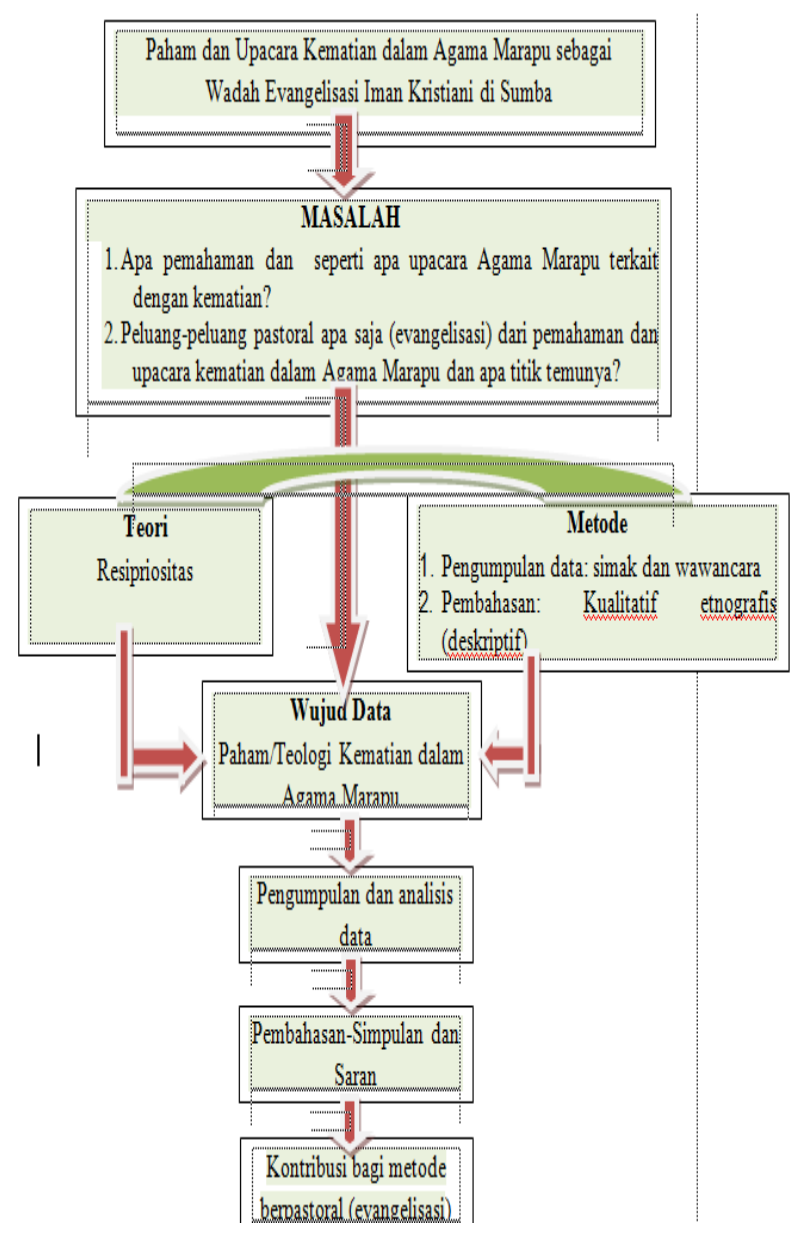

Bagan 1. Alur Kerja Penelitian

\section{Hasil dan Pembahasan}

\section{a. Pengantar}


Agama apapun dalam karya pewartaan dan misinya selalu dihadapkan dengan budaya lokal, yang di dalamnya ada agama lokalnya juga. Misi 'tradisional' agama-agama modern selama ini cenderung 'memusnahkan' agama dan budaya lokal karena dianggap sebagai penghalang penyebaran agama-agama modern itu. Fakta menunjukkan bahwa ada banyak resistensi dari masyarakat lokal (insider) terhadap tuntutan agama modern seperti itu. Mereka merasa tercabut dari akar kehidupan mereka. Akibat lebih lanjut adalah iman mereka pun dangkal-dangkal saja, selain misi ditolak. Banyak orang memeluk agama-agama modern hanya karena tuntutan sosial dan administrasi pemerintahan, bukan karena suatu pengakuan akan iman agama-agama modern. Cara bermisi seperti inilah yang kurang pas. Penelitian ini mencoba menggunakan paham-paham dan upacara-upacara budaya khususnya dalam hal kematian sebagai wadah misi (evangelisasi), dan tidak dilihat sebagai penghalang.

\section{b. Latar Belakang}

Karya misi Gereja bertemu dan bergaul dengan unsur-unsur di luar Gereja (agama lain, kebudayaan setempat dan situasi sosial kemasyarakatan) dan mengajak mereka untuk berziarah bersama menuju kepada Allah. Untuk maksud ini Gereja harus bersikap terbuka dengan situasi konkret yang ada di sekitarnya. Gereja sebagai himpunan orang beriman, tidak perlu menciptakan harapan-harapan misioner yang mustahil dapat tercapai, seperti kecenderungan untuk secara institusional mengkristenkan dunia. Hal ini berarti bahwa Gereja Lokal harus dapat hidup dan melaksanakan misi sesuai dengan tuntutan Injil untuk menjawab situasi konkret manusia, di mana ia hidup dan mau berakar sampai ke dalam sel-sel kebersamaan yang paling kecil (Edmund, 2002:220). Gereja dan kita pun harus sadar bahwa Allah yang mewahyukan Diri kepada umat-Nya hingga penampakan Dirinya sepenuhnya dalam Putera-Nya yang menjelma, telah bersabda menurut kebudayaan yang khas bagi pelbagai zaman(GS 58). Begitu pula Gereja, yang sepanjang zaman hidup dalam pelbagai situasi, telah memanfaatkan sumber-sumber aneka kebudayaan, untuk menyebarluaskan dan mewartakan Kristus kepada semua bangsa.

Seperti dikatakan oleh Konsili bahwa Gereja tidak menolak nilai-nilai yang benar dan suci (GS 53, NA 2), begitu pula sebaliknya, Gereja di dalam karya misinya dengan cara yang tepat menawarkan nilai-nilai yang dihayatinya agar tidak ditolak oleh agama dan budaya setempat. Penolakan terhadap Gereja tidak pertama-tama berarti penolakan terhadap Allah, tetapi harus ditafsir sebagai ketidak berhasilan Gereja dalam melaksanakan tugasnya sebagai sakramen keselamatan Allah. Dalam terang pemahaman yang demikian ini, saya mencoba membaca dan meneliti sekaligus melihat peluang ajaran dan pengahayatan agama Marapu dalam proses evangelisisasi iman Kristiani di Sumba yang selama ini dirasa sebagai tantangan dan hambatan. ini menjadi keprihatinan peneliti. Dalam arti ini pula peneliti mencoba melihatnya secara lain dan mencoba mencari titik temu untuk menjadikan agama marapu sebagai wadah evangelisasi khususnya terkait dengan paham kematian, bukannya sebagai penghalang.Tegasnya peneliti mau melihat peluang pastoral (evangelisasi) dari pemahaman dan upacara kematian dalam Agama Marapu.

\section{c. Sumba dan Marapu}

Sumba dan Marapu adalah dua termin yang saling memperkuat dan menjelaskan satu terhadap yang lainnya. Marapu adalah pintu masuk untuk mengenal Sumba. Marapu adalah pintu masuk untuk mengenal orang Sumba. Mempelajari dan mengenal Sumba tanpa mengenal Marapu, itu berarti kita akan mengalami kegagalan dalam menjelaskan keutuhan Sumba yang sebenarnya. Kehidupan masyarakat atau orang Sumba dipayungi, diatur dan dituntun oleh Marapu. Dalam menjelani kehidupan sehari-hari, orang Sumba selalu berusaha untuk menyelaraskannya dengan kehendak marapu. Berkat dan kutuk adalah dua kutup yang memastikan adanya peran marapu itu sendiri. orang yang mengalami berkat adalah orang yang sukses atau sanggup menyelarasakan kehidupannya dengan kehendak atau perintah marapu. Sebaliknya orang yang mengalami musibah atau kutuk adalah mereka yang melawan atau tidak mengindahkan perintah dan tuntunan marapu. Marapu adalah suatu entitas supranatural atau spiritual yang mengendalikan klehidupan manusia yang natural. Dengan kata lain, marapu menjadi sumber rujukan utama dalam mendisain kehidupan sehari-hari.

Aliran kepercayaan marapu meyakini adanya kekuasaan Yang Maha Tinggi (yang dalam termin agama-agama modern disebut Tuhan atau Allah). Wujud Tertinggi ini terlalu agung, sakral 
dan transenden, sehingga menyebut namanya saja harus mematuhi berbagai ritual yang sarat mantra spiritual, misalnya dappa numa ngara,dappa tekki tamo - dalam bahasa daerah/suku Wewewa (= Yang tidak boleh disebut namanya, dan tidak boleh disebut nama aliasnya). Ungkapan sakral lain untuk menyebut Wujud Tertinggi adalah: A kanga wolla limma a bokka wolla wa'i - dalam bahasa daerah/suku Wewewa (= Dia yang menciptakan dan Dia yang menjadikan); Ama a magholo, ina a marawi - dalam bahasa daerah/suku Wewewa (Bapa yang membuat/mengukir, Ibu yang menenun/menjadikan; Ama padewama, Ina paurrama - dalam bahasa daerah/suku Wewewa (=Tanpa Bapa kami tak bertuan, tanpa Ibu kami tak bertuan atau Bapa yang melindungi kami dan Ibu yang menjaga kami).

Mantra-mantra ini biasanya dinyanyikan oleh Rato (imam Marapu) pada malam-malam tertentu, misalnya pada malam saat upacara saiso (upacara khusus berdialog dengan Marapu dengan ujud tertentu. Syair-syair/mantra-mantra itu dinyanyikan secara bersahut-sahutan antara Rato utama dan Rato-Rato pendamping.Nyanyian itu disebut "Li'i Marapu" yang diringi dengan tabuhan gong, tambur, pekikan dan tarian, dari malam hingga pagi hari. Marapu sendiri akan menunjukan kehadirannya dengan tanda-tanda spiritual magis (misalnya jejak tapak kaki pada abu dapur, atau dalam wujud bunyian dan hewan-hewan yang dianggap keramat: kepiting, biawak, burung marapu, dll).

Oleh karena itu untuk bisa berhubungan dengan Wujud Tertinggi, para penganut Marapu harus menyampaikan segala permohonan, keluhan atau doa dalam ujud apa saja melalui perantaraperantara ulung, yang biasanya adalah para leluhur yang diyakini sudah dapat berhubungan langsung dengan Wujud Tertinggi.

Termin marapu sendiri dipahami dalam beberapa arti/makna/nama dan fungsi-fungsi spesifik yang masih berbeda-beda dari satu suku, wilayah berdeda-beda di seluruh Sumba. Beberapa diantaranya adalah sebagai berikut:

1. Marapu menunjuk secara langsung kepada Wujud Tertinggi, Yang Transenden, Yang Utuh (Ma=Yang; Rapu=Utuh/Bulat), Yang Bulat,Yang Tak terbagi-bagi.

2. Beberapa suku meyakini bahwa, Marapu adalah para leluhur yang telah meninggal dan sudah dapat masuk ke dalam ruang/wilayah sakral/suci. Oleh karena itu mereka bisa memandang dan berbicara langsung dengan Wujud Tertinggi. Nah, melalui mereka kita dapat menyampaikan permohonan, keluhan dan doa-doa kita semuanya kepada Wujud Tertinggi.

3. Walaupun kita dapat berbicara secara langsung dengan Marapu (para leluhur yang telah suci), akan tetapi para penganut Marapu dan orang Sumba pada umumnya dilarang menyebut nama nenek moyang pada tingkat ke 5. Hal ini dianggap tabu atau keramat.

4. Pendapat ini masih banyak diragukan ketepatan pemahamannya.

5. Ada Marapu yang disebut dengan sapaan Marapu Wanno:

6. Berfungsi sebagai penjaga kampung.Beberapa suku meyakini bahwa Marapu Wanno adalah roh yang diciptakan oleh Yang Maha Tinggi untuk menjaga sebuah kampung. Oleh karena itu, bagi siapa saja yang bukan penghuni asli kampung tersebut harus meminta ijin terlebih dahulu di depan pintu kampung sebelum memasuki kampung tersebut..

7. Marapu umma

8. Berfungsi sebagai penjaga/pelindung rumah/tempat tinggal.Beberapa suku memandang Marapu umma sebagai jelmaan leluhur yang sudah sampai pada kesucian.

9. Marapu Tana

10. Berfungsi sebagai penjaga padang, mata air, hutan, gunung. Marapu Tana kadang disebut juga sebagai Mori Tana/ pemilik tanah/wilayah tertentu. Warga berkepercayaan Marapu biasanya membuat upacara-upacara permintaan kepada sang Marapu Tana untuk menjaga padang, sumber-sumber mata air, hutan, gunung. Maka bagi warga berkepercayaan Marapu, sangatlah tabu apabila orang serampangan membakar ladang, merusakkan sumbersumber mata air dan menebang pohon sembarangan.

11. Marapu oma

12. Berfungsi sebagai penjaga kebun. Para petani biasanya memberikan persembahan berupa sirih pinang dan hasil-hasil kebun lain pada saat sebelum mempersiapkan lahan, saat tanam, sebelum panen dan sesudah panen. 
Aliran kepercayaan Marapu sangat menekankan prinsip keselarasan/harmoni antara manusia, alam semesta dan sang Pencipta. Aliran ini meyakini bahwa segala aspek kehidupan saling berkaitan dan merupakan satu kesatuan yang utuh.Hal ini terwujud dalam pengelolahan kehidupan sosial, budaya, rohani, lingkungan alam sebagai satu kesatuan yang utuh.Ibarat air yang mengalir dari hulu ke hilir, demikian juga perjalanan hidup manusia. Hubungan-hubungan harmonis itu kadang tampak dalam nyanyiannyanyian malam "Li'i Marapu", misalnya: "Wassu a pamori - mata wee a pamangu; Pakaninoge wee mangu mata - tangarage wassu mangu ro'o; Ina rei boto - ama rei widu" (bahasa suku Wewewa: "kayu yang bertuan - mata air yang bertuan; mata air ibarat cermin - melihat kayu yang bertuan; Ibu yang dipandang sebagai yang besar-Bapa yang dipandang sebagai yang agung".

\section{Konsep Kematian}

\section{Kematian dalam Agama Marapu}

Bagi orang Sumba pada umumnya dan Suku Wewewa pada khususnya, kematian merupakan saat peralihan dari kehidupan yang fana ke kehidupan yang Baka. Juga kematian diartikan sebagai panggilan dari yang empunya kehidupan untuk kembali kepadanya. Istilah setempat dikatakan; "kalokana kalere u'du na katanga" (harafiahnya: kuda yang diberi tali yang panjang dan dilepas, tetapi pada saatnya tali itu akan digulung kembali). Arti dari ungkapan ini adalah manusia ini sesungguhnya adalah ternak dari Allah yang paling istimewa dan karena itu tidak boleh disembelih. Panjangnya tali sebenarnya melambangkan lamanya perjalanan hidup seseorang.

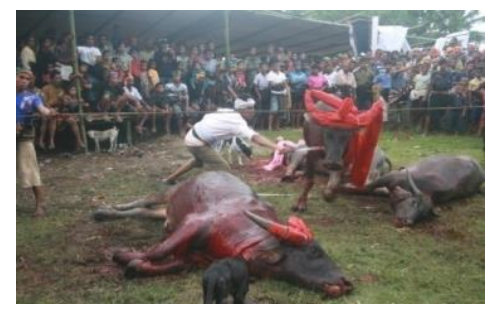

Konsep Marapu tentang kematian ini sedikit sama dengan konsep Kristiani, khususnya dalam agama Katolik. Dalam ajaran Gereja Katolik pun, kematian tidak pernah diartikan sebagai suatu kebinasaan. Dalam Gereja Katolik, kematian adalah Mahkota kehidupan, peristiwa puncak kehidupan. Hidup tidak lenyap, melainkan hanya diubah.
Kematian bagi orang Katolik merupakan saat kita mempercayakan diri secara total kepada Kristus, kebangkitan dan kehidupan kita, saat perjumpaan abadi dengan Dia, pokok pengharapan kita yang mengantar kita pulang ke rumah-Nya sendiri.

Ada perbedaan yang substantif di sini antara konsep orang Marapu dan konsep dalam ajaran Gereja Katolik. Orang Marapu memahami kematian sebagai sebuah kelanjutan untuk masuk dalam kehidupan yang lain. Konsep Gereja Katolik tidak berhenti di sini. Yang lebih utama pada peristiwa kematian adalah saat penyerahan diri total kepada yang empunya kehidupan yakni Allah. Kematian adalah saat manusia kembali kepada pemilknya untuk mendapatkan kepenuhan hidup yang di dalamnya tidak ada derita. Jaminan akan kepenuhan hidup ini adalah kurban Kristus di Salib.

1. Macam-macam kematian

Orang Sumba pada umumnya dan suku Wewewa pada khususnya, Membedakan kematian dalam dua jenis, yakni kematian normal (kematian wajar) dan kematian tidak normal (kematian panas, kematian tidak wajar,).

a. Kematian normal atau wajar (rarano winno, modu na utta)

Bagi orang Sumba pada umumnya dan orang Wewewa pada khususnya, kematian normal adalah kematian yang paling mulia dan terhormat. Kematian normal ini dalam istilah wewewa; rarano wino, modu na uta. Artinya; pinang yang buahnya sudah matang dan sirih yang buahnya sudah masak dengan sendirinya jatuh. Ungkapan ini mau menggambarkan bahwa orang yang meninggal karena umur tua itu karena memang saatnya, ibarat orang yang mengadakan perjalanan jauh kini ia sudah sampai pada ujung dari perjalanan itu sendiri.

b. Kematian tidak normal atau tidak wajar atau panas (wino mbata deta, pare buka moro)

Kematian tidak normal atau meninggal sebelum waktunya ini dalam keyakinan orang wewewa disebabkan oleh beberapa hal diantaranya; karena kecelakaan, pembunuhan, sakit penyakit dan lain sebagainya.

Untuk kematian yang wajar, orang tidak akan membuat ritual penyucian lagi, karena dia dianggap sudah suci. Dan itu dilihat dari umurnya yang panjang. Bagi orang Sumba, meninggal karena usia yang tua, sudah waktunya untuk meninggal adalah sangat terhormat. 
Lain halnya dengan kematian yang tidak wajar atau kematian panas.Kematian panas adalah kematian sebelum waktunya.Kematian panas atau tidak wajar merupakan sebuah musibah yang memilukan, menakutkan dan menyedihkan. Orang yang meninggal sebelum waktunya dianggap kotor. Jiwa orang yang mati dengan cara demikian ini masih mengembara di mana-mana dan tidak tenang. Ia tidak bahagia dan sangat mengharapkan pertolongan kaum keluarganya yang masih hidup. dalam arti ini maka perlu ritual pemulihan.

\section{Kematian dalam Agama Katolik}

Kematian merupakan pengalaman iman yang paling istimewa, di mana mana manusia pada akhirnya berjumpa dengan Allah yang adalah pemberi hidupnya. Kematian merupakan saat di mana manusia beralih dari waktu dan ruang ke alam baka. Maut bukanlah sesuatu yang entah kapan menimpah kita. Maut itu kenyataan keterbatasan kita. hidup kita mempunyai awal dan akhir. dengan demikian segala sesuatu yang kita lakukan bersiaft terbatas dan fana, tetapi tidak tanpa arti. dalam hidup di dunia ini, hidup rahmat yang abadi sudah dimulai. kita harus mempergunakan waktu yang ada (Ef 5:16), sebab justru dalam waktu ini kita membentuk hidup kita terhadap Tuhan. Kesadaran akan kefanaan hidup ini dapat menjadi alasan sewaktu-waktu sadar bahwa kita hidup di hadapan Tuhan. Maut membawa ke dalam hidup kita kesadaran akan tujuan hidup yang sejati. Hidup memang memang bersifat sementara, tetapi sikap hidup yang kita ambil sekarang bersifat defenitif. "Barang siapa menyangkal Aku di depan manusia, Aku juga akan menyangkal dia di depan Bapa-Ku yang di surga" (Mat 10:33). Kematian berarti penyelesaian "pengembaraan"manusia ( Ibr 11:13; 1Ptr $1: 1 ; 2: 11)^{3}$

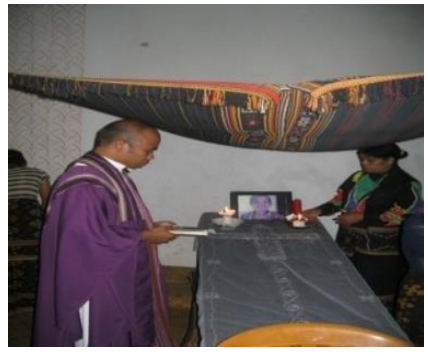

Oleh Kristus, kematian Kristen menjadi postitif. "Bagiku hidup adalah Kristus dan mati

${ }^{3}$ KWI, 1996. Iman Katolik. Yogyakarta, Kanisius. adalah keuntungan" (Flp.1:21). "Benarlah perkataan ini: jika kita mati dengan Dia, kita pun akan hidup dengan Dia" (2Tim 2:11). Aspek yang sungguh baru pada kematian Kristen terdapat di dalam hal ini: Oleh pembaptisan warga Kristen secara sakramental sudah "mati bersama Kristus" supaya dapat menghidupi satu kehidupan baru. Kalau kita mati dalam rahmat Kristus, maka kematian badani menyelesaikan "mati bersama Kristus" ini dan dengan demikian melaksanakan secara defenitif penggabungan kita dalam Dia oleh karya penebusan-Nya. Dalam kematian, Allah memanggil manusia ke dalam diri-Nya. Karena itu seperti Paulus, warga Kristen dapat merindukan kematian: "Aku ingin pergi dan diam bersamasama dengan Kristus" (Flp 1:23) ${ }^{4}$.

Dalam perspektif iman kristiani, dosa mendatangkan maut dan bahwa maut mengakhiri segalanya. Tetapi maut bukan akhir dari segalanya atau batas akhir hidup kita. Kematian merupakan jalan masuk kepada penebusan dan pemuliaan kita dalam Allah.Kematian sebagai sarana penebusan berkaitan erat dengan pribadi Kristus.Dalam Yesus Kristus dan berkat kematianNya, manusia boleh terus berharap pada penyelamatan Allah.

Karena itu kematian sebagai sarana penebusan lalu ditempatkan dalam perspektif kematian Kristus. Dalam dan melalui Yesus Kristus, Allah menyelamatkan manusia dari dosa dan kematian.Tindakan penyelamatan Allah bukan demi kepentingan Allah, melainkan demi manusia.Allah sebagai Allah yang maha cinta tidak membiarkan ciptaan kesayanganNya binasa dari mati karena dosa.Sebab Allah telah menciptakan manusia untuk hidup.Daya pengerak karya penyelamatan Allah ialah kasih (bdk. Yoh 3: 16).

\section{Evangelisasi Iman dalam Konteks Budaya}

Karya misi Gereja bertemu dan bergaul dengan unsur-unsur di luar Gereja (agama-agama tetangga, kebudayaan-kebudayaan setempat, situasi sosial kemasyarakatan) dan mengajak mereka untuk berziarah bersama menuju Allah. Untuk maksud ini Gereja harus bersikap 'terbuka' terhadap 'tetangga' dengan mengungkapkan imannya di tengah-tengah situasi dan lingkungan hidupnya yang konkret (Woga, 2002:220). Di tengah dunia yang demikian aneka itu, Gereja kudus dalam melakukan kegiatan evaneglisasi harus membuka diri dan menerima kebenaran yang ada dalam budaya setempat,

${ }^{4}$ Bdk. Katekismus Gereja Katolik, 1998:260 
mengingat Gereja kudus juga adalah himpunan manusia yang tidak sempurna. di luar diri Gereja masih ada begitu banyak kebenaran yang bisa dilihat dan dijadikan sarana keselamatan.

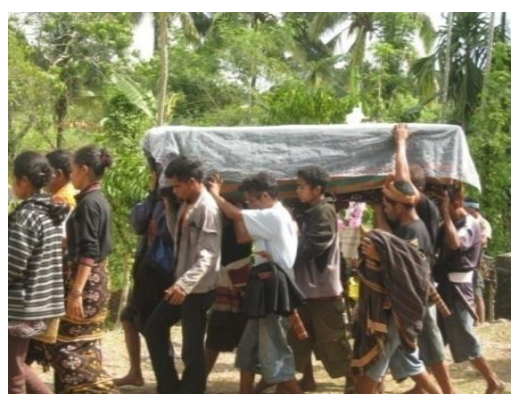

Hal ini sejalan dengan apa yang dikatakan dalam Nostra Aetate (NA 2), bahwa Gereja tidak menolak nilai-nilaiyang benar dan suci, begitu pula sebaliknya Gereja di dalam karya misinya dengan cara yang tepat menawarkan nilai-nilai injili yang dihayatinya agar tidak ditolak oleh agama dan budaya setempat. Gereja dalam evangelisasinya harus tampil dengan wajah lokal, wajah yang familiar, wajah yang dikenal, agar Gereja tidak menjadi seperti menara gading yang sulit dijangkau dan tidak dipahami. Gereja hanya dapat secara tepat melakukan evangelisasi kalau ia menyampaikan Sabda Allah itu dalam suatu realitas konkret, dari suatu kebudayaan yang konkret, dalam suatu cara yang sedemikian rupa sehingga pendengarnya mengerti dan menanggapinya. Demikian iman menjadi menetap dan bertumbuh.

Dalam konteks ini, menjadi penting apa yang disebut sebagai inkulturasi Gereja. Inkultuarasi Gereja diartikan sebagai pengalaman Kristen dari suatu Gereja lokal ke dalam kebudayaan umatnya sedemikian rupa, sehingga pengalaman ini tidak hanya menyatakan dirinya dalam unsur-unsur kebudayaan tersebut, tetapi menjadi suatu kekuatan yang menjiwai, mengarahkan serta memperbarui kebudayaan tersebut sampai menciptakan suatu kesatuan dan persekutuan baru, tidak hanya dalam kebudayaan tersebut tetapi juga sebagai pengayaan Gereja Universal.

\section{Evangelisasi Iman Kristiani dalam Kepercayaan Marapu}

Sebagaimana sudah dikatakan pada awal tulisan ini, bahwa Sumba dan Marapu merupakan dua termin yang saling mengandaikan. Sumba adalah marapu dan marapu adalah Sumba. Mengenal Sumba berarti mengenal marapu.
Marapu menjadi pintu masuk satu-satunya untuk mengenal Sumba. Pertanyaannya adalah bagaimana Iman Kristiani bisa diwartakan kepada orang Sumba yang kehidupannya sangat kental dengan keyakinan marapu. Apakah ada pintu yang bisa menghubungkan antara iman kristiani dan marapu? Atau apakah ada kepercayaan yang sama yang bisa mendamaikan di antara keduanya.

Dalam kepercayaan marapu, khususnya dalam kepercayaan mereka akan peritiwa kematian, ada beberapa poin teologi iman marapu dan iman kristiani yang bisa didamaikan bahkan menjadi wadah pewartaan iman kristiani itu sendiri

\section{Konsep kematian itu sendiri}

a. Konsep kematian dalam Agama Katolik

Kematian merupakan pengalaman iman yang paling istimewa, di mana manusia pada akhirnya berjumpa dengan Allah yang adalah pemberi hidupnya. Kematian merupakan saat di mana manusia beralih dari dunia dan hidup yang fana ke alam dan dunia kehidupan yang baka.

b. Konsep kematian dalam Agama Marapu

Kematian dalam Agama Marapu pun sungguh dipahami sebagai suatu peralihan dan bukan akhir dari segalanya. Dalam agama marapu, kematian dilihat sebagai cara untuk bertemu dan berkumpul kembali dengan para leluhur dan marapu itu sendiri. Kematian adalah saat di mana manusia akan mengalami suka cita dana hidup dalam keabadian dengan Dia yang adalah sumber dan tujuan hidup itu sendiri. Dia yang sangat kudus dan karena itu tidak boleh disebutkan namaNya memanggil kembali manusia untuk tinggal bersamaNya.

\section{Titik Temu untuk Evangelisasi}

Terkait dengan konsep kematian ini Gereja hadir dan meneguhkan, menyakinkan sekaligus memberi pemahaman bahwa memang kematian bukanlah akhir dari kehidupan manusia, melainkan sebagai jalan untuk masuk ke kehidupan yang sebenarnya, kehidupan yang mulia abadi, kembali dan bersatu dengan Dia yang adalah penyelenggara kehidupan itu sendiri.

Hal kedua yang juga yang harus disampaikan pada evangelisasi ini adalah memperkenalkan nama Allah kepada mereka. Gereja hadir dan mengatakan bahwa Dia yang tidak disebutkan namaNya itu dalam agama Katolik dikatakan sebagai Allah, pencipta dan penyelenggara kehidupan kita. Dengan kematian, kita semua manusia akan kemabki dan berkumpul 
bersama Allah, sumber dan tujuan kehidupan itu sendiri.

a. Relasi antara yang sudah meninggal dan yang masih hidup

1. Konsep relasi antara yang sudah meninggal dan yang masih hidup dalam Agama Katolik

Gereja dalam ajaran Agama Katolik adalah persekutuan antara orang yang masih hidup dan yang sudah meninggal. Ajaran ini mau menjelaskan bahwa, pertama, kematian bukanlah akhir dari kehidupan manusia. Dan yang kedua adalah relasi antara orang yang masih hidup dengan mereka yang sudah meninggal, tetap ada.

Dalam Agama Katolik juga diajarkan dan juga sungguh diyakni bahwa relasi antara orang masih hidup dan yang sudah meninggal itu pun dalam rangja untuk saling membantu doa. Untuk keselamatan mereka yang sudah meninggal, orang yang masih hidup bisa membantunya dengan doa doa. Sebaliknya untuk kebaikan dan berkat bagi mereka yang masih hidup, kita bisa memohonkan doa dari mereka yang sudah meninggal.

2. Konsep relasi antara yang sudah meninggal dan yang masih hidup dalam Agama Marapu

Dalam Agama Marapu, relasi antara mereka yang masih hidup dengan mereka yang sudah meninggal tetap ada. Dalam Agama Marapu, sebagaimana juga ada dalam Katolik bahwa, relasi itu juga dipahami dalam rangka untuk saling membantu. Mereka yang sudah meninggal sangat mengharapkan doa dan bantuan lain dari mereka yang masih hidup agar mereka bisa segera memperoleh kehidupan yang mulia di surga, atau wanno kalada.Sebaliknya, mereka yang masih hidup juga sangat mengharapkan bantuan dari mereka yang sudah meninggal untuk memberi berkat pada mereka. Diyakini bahwa, orang yang sudah meninggal bisa memberikan berkat dan kutuk bagi mereka yang masih hidup. Berkat dan kutuk itu tergantung seberapa intens relasi dengan mereka yang sudah meningal. Mereka yang sudah meninggal telah bersekutu dengan marapu, maka lebih mudah untuk membantu mereka yang masih hidup.

\section{Titik Temu untuk Evangelisasi}

Baik Agama Katolik maupun Agama Marapu sama sama percaya dan meyakini bahwa, relasi antara mereka yang masih hidup dan mereka yang sudah meninggal tetap ada dan saling membantu.

Pada poin ini, Gereja hadir untuk meneguhkan dan membenarkan bahwa memang relasi itu tetap ada dan terjalin. Relasi untuk saling membantu itu memang ada dan sama dari kedua agama ini. Gereja hadir dan memperkenalkan bahwa mereka yang sudah meninggal itu menjadi orang kudus karena bersekutu dengan Allah. Inilah yang dalam Gereja Katolik dikatakan sebagai persekutuan kudus umat beriman. Dalam persekutuan dengan Allah itulah kita mempunyai alasan untuk meminta dan memohon doa mereka. Tetapi sebaliknya, mereka yang masih hidup pun terus mendoakan mereka, agar persekutuan dengan Allah itu segera terjadi.

\section{b. Kehidupan sesudah kematian}

1. Konsep kehidupan sesudah kematian dalam Agama Katolik

Luk 16.22.23, Luk 20.27“40, Mat 25.31.33

Dalam kita suci ada perdebatan antara Yesus dan orang Zaduki tentang kehidupan sesudah kematian, atau tentang kebangkitan orang mati.

Dari Teks Luk 20.27 40, dan juga masih banyak teks lain yang berbicara tentang kehidupan sesudah kematian, menjadi jelas buat kita bahwa, orng akan hidup dalam kemuliaan sebagaimana malaikat seteah seseorang beralih dari dunia ini. Orang hidup dalam persekutuan dengan Allah. Dalam persekutuan dengan Allah itu, segala yang duniawi hilang. Orang menjadi kudus karena dikuduskan oleh Allah dan hidup sebagaimana malaikat malaikat.

2. Kehidupan sesudah kematian dalam Agama Marapu 
Dalam Agama Marapu, pemahaman akan kehidupan sesudah kematian sedikit berbeda dengan apa yang diajarkan dalam Agama Katolik. Bagi orang marapu, kehidupan setelah kematian itu persis sama dengan di dunia nyata ini. Apa yang dibuat, dikerjaka. Dibutuhkan, bahkan segala keinginan di dunia nyata ini pun sama dengan di dunia setelah kematian itu. Pemahaman atau keyakinan seperti ini menjadi alasan mengapa mereka memotong hewan waktu penguburan, menyertakan kalekunya dalam peti kematian, dan lainßlain karena semuanya itu dibutuhkan di sana, termasuk lahan untuk bercocok tanam.

\section{Titik Temu untuk Evangelisasi}

Baik agama Katolik maupun Marapu sama sama yakin dan percaya bahwa ada kehidupan di dunia seberang sana. Artinya setelah kehidupan di dunia nyata ini, atau setelah beralih dari dunia yang fana ini, orang akan mengalami kehidupan yang lain, dengan situasi yang berbeda beda antara agama Katolik dan Marapu.

Pada poin ini Gerja hadir untuk mewartakan imannya bahwa, kehidupan di dunia seberang itu sama sekali berbeda dengan yang ada nyata di dunia ini. Gereja pertama tama menegaskan dan meneguhkan keyakina mereka bahwa memang ada kehidupan di dunia seberang sana. Itu benar. Tetapi setelah orang beralih dari dunia yang fana ini, orang akan mempunyai kehidupan dan situasi yang sangat berbeda. Hidup dalam roh dan bersekutu dengan Allah. Segala hasrat dan keinginan duniawi hilang.

\section{c. Dosa dan Penebusan}

Dosa dan penebusan dalam setiap agama mempunyai hubungan saling mengandaikan.

1. Konsep dosa dan penebusan dalam Agama Katolik

Katekismus Gereja Katolik (KGK) mendefinisikan bahwa dosa adalah satu pelanggaran terhadap akal budi, kebenaran, dan hati nurani yang baik. Dosa tidaklah hanya sebatas perbuatan; KGK mengutip kata-kata seorang Bapa
Gereja dan Doktor

Gereja, Santo Agustinus, bahwa dosa adalah

"perkataan, perbuatan, atau keinginan yang bertentangan dengan hukum abadi". Dosa merupakan suatu penghinaan terhadap Allah, pemberontakan terhadap kasih Allah kepada manusia, dan membalikkan hati manusia dari Allah.

Sama seperti dosa asal, dosa adalah satu

bentuk keangkuhan dan ketidaktaatan ke pada Allah; bertentangan dengan ketaatan Yesus yang melaksanakan keselamatan. Sehingga Santo Agustinus, mengatakan bahwa dosa adalah "cinta diri yang meningkat sampai menjadi penghinaan Allah". Dalam KGK tertulis bahwa akar dosa terletak di dalam hati manusia, dalam kehendak bebasnya (Matius 15:19-20). Namun dalam hati manusia juga ada kasih, sumber segala perbuatan baik dan suci, yang terluka karena dosa.

Sementara itu penebusa dalam Agama katolik dilihat sebagai cara Tuhan sendiri untuk menyelamatkan umatnYa. Artinya usaha untuk menyelamatkan manusia itu melibatkan intervensi ilahi, tidak semata usaha manusia.Dan penebusan dalam Agama Katolik diletakkan pada pengurbanan Kristus di Salib.Pengurbanan Diri Tuhan Yesus menjadi pepulih hubungan antara Allah dan manusia karena dosa.Dalam arti ini penebusan dipahami sebagai pendamaian dan diselamatkannya manusia dari hukuman dosa.Dengan penebusan Tuhan maka, relasi antara Allah dan manusia tersambung kembali, dan manusia mendaptkan keselamatan berkat darah dan salib Tuhan itu sendiri.

2. Konsep dosa dan penebusan dalam Agama Marapu

Dalam Agama Marapu sebagaimana dalam Agama Katolik, dosa dipahami sebagai pelanggaran atau ketidakpatuhan serta ketidaksetiaan manusia terhadap segala perintah marapu. Dasar dari pemahaman ini adalah, marapu selalu mengajarkan yang baik dan benar, juga memerintahkan 
untuk melakukan yang baik dan benar. Marapu selalu menuntut keharmonisan dalam hidup.

Sementara itu konsep penebusan dalam Agama Marapu dipahami sebagai usaha dari orang yang masih hidup, khususya kaum keluarganya untuk menyelamatkan jiwa dari orang yang sudah meninggal. Usaha usaha yang dibuat itu dalam bentuk upacara atau ritual ritual pemulihan.Dan dalam ritual pemulihan ini, orang marapu menumpahkan darah hewan sebagai symbol sekaligus persembahan silih atas dosa yang telah dibuat oleh orang yang sudah meninggal itu. Penebusan dan keselamaan dalam arti itu sebagaimana dalam Agama Katolik, melibatkan pihak lain.

\section{Titik temu untuk Evangelisasi}

Baik Agama Katolik mapun Agama Marapu, keduanya sama sama memahami bahwa dosa berarti suatu perbuatan yang salah dan keliru. Dosa berarti suatu perilaku yang melanggar perintah.Dosa berarti suatu bentuk ketidasetiaan pada Dia yang tertinggi.Dosa berarti perilaku yang merusak keharmonisan dan relasi.Pada poin ini, Gereja hadir untuk menegaskan dan meneguhkan bahwa dosa berarti suatu perbuatan yang melanggar, suatu perbuatan merusak dan suatu bentuk ketidaksetiaan pada hal hal yang baik.Dosa berarti suatu perbuatan yang tidak baik atau jahat.

Sementara itu pemahaman tentang penebusan di antara kedua agama ini cukup berbeda walaupun sama sama membutuhkan perantara.dalam agama Katolik, Pengurbanan Kristus di Salib menjadi jaminan dan jalan penebusan itu sendiri. Yesus menumphakan darahNya untuk menebus dosa manusia. Dalam Agama Marapu penebusan dosa untuk keselamatan diletakan pada ritual pemulihan atau rekonsiliasi yang di dalamnya harus ada darah hewan yag ditumpahkan sebagai silih atas dosa. Upacara atau ritual seperti ini sama dengan apa yang dilakukan oleh orang Yahudi pada waktu itu.
Pada poin ini Gereja hadir dan memperkenalkan bahwa yang sebenarnya menebus dan menyilih dosa kita adalah darah Tuhan Yesus di salib yang mengorbankan dirinNya untuk keselamatan kita manusia. Korban Kristus itulah yang menjadi jaminan keselamatan kita, bukan lagi darah binatang yang ditumpahkan dalam ritual ritual pemulihan

\section{Penutup dan Saran}

Berikut diberikanbeberapa kesimpulan kecil sebagai intisari dari semua pembahasan dalam penelitian sekaligus saran.

a. Evangelisasi dalam Konteks

Dari hasil penelitian dan semua pembahasan sebagaimana yang sudah diuraikan pada poin empat di atas, menjadi jelas buat kita arti sebuah budaya bagi kegiatan evangelisasi iman. Iman tumbuh dan berkembang serta berakar dalam budaya. Persoalan bagi gereja dan para pewarta adalah bagaimana memahami falsafah atau filosofi dari berbagai praktek budaya lokal dan mencarai ruang untuk dialog dan evangelisasi. Gereja dalam hal ini tidak boleh mengambail jarak atau bahkan menolak praktek budaya lokal dan menuduhnya sebagai yang kafir sebelum mengetahui filosofi dan teologi di baliknya itu. Pemahaman budaya yang lebih utuh, membantu para pewarta sabda untuk sanggup mengakarkan iman kristiani secara kontekstual.

Hal ini sejalan dengan apa yang dikatakan oleh Konsili, bahwa Gereja tidak menolak nilainilai yang benar dan suci (NA 2), begitu pula sebaliknya Gereja di dalam karya misinya dengan cara yang tepat menawarkan nilai-nilai injili yang dihayatinya agar tidak ditolak oleh agama dan budaya setempat. Penolakan terhadap Gereja tidak pertama-tama berarti penolakan terhadap Allah, tetapi harus ditafsirkan sebagai ketidakberhasilan Gereja dalam melaksanakan tugasnya sebagai sakramen keselamatan Allah.

Setiap Gereja lokal mempunyai tugas dan tanggung jawab untuk secara penuh tampil sebagai Gereja Kristus yang diutus untuk melanjutkan karya pewartaan Kerajaan Allah yang telah dimulai dan terpenuhi di dalam Diri Yesus Kristus. Sebagaiman Kerajaan Allah meruypakan sapaan Allah (yang membebaskan) terhadap manusia pada waktu, tempat dan kondisi dunia tertentu, demikian pula Gereja dalam tugas misionernya, harus tampil 
sebagai organ pembebas sesuai dengan kondisi dunia di mana Gereja hadir sebagai sakramen keselamatan. Misi Gereja harus terbuka dan kontekstual (Woga, 2002:221).

b. Gereja yang Inkulturatif

Hidup menggereja yang institusional-sentralis adalah masa lampau. Sentralisasi sebagai orientasi ke pusat (Roma;hierarki) membuat Gereja-Gereka setempat menjadi asing terhadap dirinya sendiri dan dunia sekitarnya. Padahal sabda yang diwartakan di dalam dan melalui karya misi harus dapat berinkarnasi ke dalam dunia yang didatanginya, juga kalau dunia tidak mengenal dan menerimanya (bdk. Yoh 1:10-11). Karakter Inil sebagai Sabda Tuhan ialah kesediaan untuk mengosongkan diri agar dapat menjadi salah satu unsur dari dunia sekitarnya dan terlibat secara penuh di dalam kehidupannya. Dengan cara ini, sabda Allah dapat mengubah dan memperbarui hidup sekitarnya (EN 18)., tidak merupakan unsur asing tetapi memperbarui sambil berabaur. Eksklusivitas adalah tanda bahwa Gereja sedang tidak menyandang sabda Tuhan (Woga, 2002:222). Gereja dalam evangelisasinya, harus hadir dan menjadi bagian dari budaya setempat, sambil menanamkan dirinya, mengembangkan dirinya dan mengakarkan dirinya dalam konteks, sehingga evangelisasi sungguh mempunyai daya sentuh, daya ubah dan daya memperbarui. Gereja yang berwajah budaya lokal adalah Gereja yang inkulturatif, Gereja yang menjadi milik umat setempat. Inilah yang menjadi kunci berhasilnya sebuah evangelisasi.

\section{Daftar Pustaka}

Adam, Moni. 1966. Life and Death on Sumba. Rotterdam: Museum voor Land-en Volkenkunde te Rotterdam

Benediktus, Paus. 2012. Katekismus Populer. Yogyakarta: Kanisius

Endaswara, Suwardi. 2006. Metodologi Penelitian Kebudayaan. Yogyakarta: Gadjah Mada University Press

Fransiskus, Paus. 2013. Evangelii Gaudium. Jakarta: KWI

Fernandes, Stefphanus Ozias. 1990. Kebijaksanaan Manusia Nusa Tenggara Timur Dulu dan Kini. Maumere Flores: Ledalero.

Hambarani, Pala. 1982. "Praktek-Praktek Agama Marapu yang Masih Nampak dalam Kehidupan Aggota Jemaat Gereja Kristen
Sumba-Ngalu". Thesis Fakultas Theologia Universitas Kristen Satya Wacana Salatiga

Jorgensen, Danny L. 1989. Partisipant Observation, A Methodology for Human Studies. London. England.

Kapita, Oc.H. 1976. Masyarakat Sumba dan Adat Istiadatnya. Waingapu. Gereja Kristen Sumba

1976. Sumba di dalam Jangkauan Jaman. Waingapu: Gereja Kristen Sumba

Kleden, Dony. 2013. Politik Resiprositas Kedde. Yogyakarta. Andi.

Koenjaraningrat.1993. Metode-Metode Penelitian Masyarakat. Jakarta:PT. Gramedia

KWI. 1996. Iman Katolik, Buku Informasi dan Referensi. Yogyakarta. Kanisius

Magnis-Suseno, Frans. 2014. Iman dan Hati Nurani. Jakarta: Obor.

Mauss, Marcel. 1992. Pemberian. Jakarta: Yayasan Obor

Radcliffe-Brown, A,R. 1965. Structure and Function in Primitive Society. New York: The Free Press Woga, Edmund. 2002. Dasar-Dasar Misiologi. Yogyakarta: Kanisius

Sahlins, Marshall. 1974. Stone Age Economics. London: Tavistock Publication

Spradley, James P. 1997. Metode Etnografi. Yogyakarta: Tiara Wacana

Syukur Diseter, Nico. 2004. Teologi Sistematika 2. Yogyakarta. Kanisius

Tunggul, Nggodu.2000. Lintasan Budaya Sumba Timur: Etika Moralitas. Jakarta: Pro Millenio Center

Wellem, F.D. 2004. Injil dan Marapu., Studi Historis-Teologis tentang Perjumpaan Injil dengan Masyarakat Sumba pada Periode 1876-1990. Jakarta: Gunung Mulia.

Woga, Edmund. 2002. Dasar-Dasar Misiologi. Yogyakarta. Kanisius

Yewangoe, A.A. 1980. "Korban dalam Agama Marapu". Waingapu: Peninjau

Vredenbregt, J. 1970. Metode dan Teknik Penelitian Masyarakat. jakarta: PT. Gramedia 